\title{
Investigasi Perilaku Compulsive Buying Berdasarkan Pembayaran Non- Tunai, Lingkungan Sosial, dan Kondisi Keuangan
}

\author{
Berto Mulia Wibawa ${ }^{1}$, Malvin Piero ${ }^{2}$, Ribka Anintha Miyagi ${ }^{3}$ \\ ${ }^{1,2,3}$ Fakultas Bisnis dan Manajemen Teknologi, Institut Teknologi Sepuluh Nopember, Surabaya, 60111. \\ E-mail: berto@mb.its.ac.id ${ }^{1}$, malvinpiero17@ gmail.com $^{2}$, miyagiribka143@gmail.com ${ }^{3}$
}

\author{
Diterima: $12 / 02 / 2019$ \\ Direview: $20 / 04 / 2020$ \\ Diterbitkan: 30/07/2020
}

Hak Cipta @ 2020 oleh Penulis (dkk) dan Jurnal Sosial Humaniora (JSH)

*This work is licensed under the Creative

Commons Attribution International License (CC BY 4.0).

http://creativecommons.org/licenses/by/4.0/ Open Access

\section{Subject Area : Psychology (Psikologi), Economy (Ekonomi)}

\section{Abstract}

The behavior of people living in Surabaya is different from people from other cities, including the shopping behavior of the students in Surabaya. Students in Surabaya have more temptation to behave negatively in shopping. It encourages the occurrence of irregularities in shopping. Such action is classified as compulsive buying. Compulsive buying is a spending behavior based on a strong desire that makes people lose consciousness and can not control themself. This study aims to analyze the effect of sales promotion, cashless payment, social environment, and financial condition on compulsive buying on university students in Surabaya. The method used is descriptive analysis with multiple cross-sectional designs. Data were analyzed with Structural Equation Modeling. The result of this research showed that sales promotion, cashless payment, and financial condition variables have a positive effect on compulsive behavior on university students in Surabaya.

Keywords: Compulsive buying; sales promotion; cashless payment; social environment; financial condition

\section{Pendahuluan/Latar Belakang}

Penyimpangan dalam berbelanja terjadi karena banyaknya kebutuhan seseorang. Ada dua jenis penyimpangan yang terjadi, yaitu impulsive buying dan compulsive buying. Valence et al (1988) menyatakan bahwa saat ini muncul fenomena compulsive buying yang dianggap menyimpang oleh masyarakat. King (1981) dan Lawrence et al. (2014) mendefinisikan compulsive buying sebagai perilaku konsumen yang addicted atau kecanduan dengan belanja hingga tidak menyadari dirinya sendiri. Compulsive buying merupakan sebuah proses belanja secara berkala yang seolah-olah sudah menjadi kewajiban bagi pelakunya, bersifat sangat mengganggu dan tidak memiliki makna atau tidak berguna (Parzalis et al, 2008). Dengan adanya perilaku kompulsif dalam berbelanja, maka seorang konsumen dituntut untuk lebih bijak dalam berbelanja (Naomi \& Mayasari, 2008; Felicia et al., 2014). Perilaku kompulsif akan merugikan konsumen karena akan membuatnya mengeluarkan uang secara berlebih meski tidak pasti membutuhkan barang tersebut.

Pada toko-toko ritel di Indonesia, sering sekali memberikan promosi yang menarik perhatian. Hassay dan Smith (1996) serta Kellet dan Bolton (2009) menyatakan bahwa compulsive buying lebih mudah dan sering terjadi pada toko ritel. Pembelian yang dilakukan di toko ritel juga dipermudah dengan pembayaran tunai maupun non tunai. Metode pembayaran tunai yang selama ini dilakukan oleh masyarakat sudah mulai bergeser pada pembayaran dengan cara non tunai. Pembayaran dengan cara non tunai membuat seseorang memiliki kebebasan dalam menggunakan uangnya. Di Indonesia, pemerintah sedang menggalakkan transaksi non tunai 
yang tertuang dalam Gerakan Nasional Non Tunai (GNNT) yang diluncurkan pada 2014. Terdapat berbagai jenis pembayaran non tunai seperti kartu kredit, kartu debit atau kartu ATM, serta model e-money yang baru berkembang belakangan ini. Faktor lain yang mendorong terciptanya compulsive buying adalah adanya pengaruh lingkungan sosial. Lingkungan sosial sendiri dapat berupa keluarga, teman, saudara, maupun orang lain yang ada di sekitarnya. Menurut Valence et al (1988), keluarga, orang terdekat dalam rumah, serta teman dapat memberikan pengaruh dalam perilaku kompulsif yang terjadi pada seseorang. Situasi atau kebiasaan yang sering dilihat oleh seseorang akan mendorong seseorang untuk melakukan hal yang sama dengan apa yang ia lihat (Murray, 1953).

Kebiasaan dalam berperilaku kompulsif juga didorong oleh kondisi keuangan. Pada umumnya, orang dengan kondisi keuangan yang lebih stabil dan baik akan memiliki kebiasaan compulsive yang lebih tinggi dibandingkan dengan orang dengan keadaan ekonomi yang kurang. Penelitian mengenai compulsive buying ini menjadi penting dan dianggap perlu untuk dilakukan, karena perilaku kompulsif yang timbul di kalangan mahasiswa dapat memberikan dampak negatif, seperti membentuk budaya konsumtif, hedonisme, dan penggunaan uang yang tidak tepat. Oleh karena itu, penting untuk diteliti bagaimana pengaruh promosi penjualan, pembayaran non tunai, lingkungan sosial, dan kondisi keuangan terhadap compulsive buying pada mahasiswa di Surabaya. Tujuan penelitian ini diantaranya: (1) menganalisis karakteristik pola konsumsi mahasiswa di Surabaya, (2) menganalisis pengaruh variabel promosi penjualan, pembayaran non tunai, lingkungan sosial, dan kondisi keuangan terhadap compulsive buying mahasiswa di Surabaya, dan (3) merumuskan strategi penghindaran compulsive buying.

Menurut Parzalis et al (2008), definisi compulsive buying merupakan sebuah proses belanja secara berkala yang seolah-olah sudah menjadi kewajiban bagi pelakunya, bersifat sangat mengganggu dan tidak memiliki makna atau tidak berguna, serta menurut Weinstein et al. (2016) compulsive buying merupakan bentuk kegiatan membeli berulang sebagai respon primer terhadap suatu perasaan dan kegaiatan negatif. Perilaku kompulsif ini terjadi pada berbagai produk, misalnya drugs, eating disorders, compulsive sexuality, pathological gambling, dan kleptomania (Faber et al, 2014). Terdapat banyak hal yang mendorong terjadinya compulsive buying. Perilaku kompulsif ini biasanya berhubungan erat dengan kondisi sosial demografi dan kondisi psikologi dari penderitanya (Raab et al, 2011).

Penderita compulsive buying umumnya memiliki ketidakmampuan mengontrol diri, didominasi oleh wanita, mengalami kegelisahan sosial, depresi, kesadaran diri yang rendah, berorientasi pada materi, dan tidak mampu mengelola keuangannya (Dittmar, 2005; Raab et al, 2011; Ridgway et al, 2008). Compulsive buying sendiri memiliki empat tipe yaitu ketidakmampuan diri untuk mengontrol (Christenson et al., 1994; Achtziger et al., 2015), perilaku compulsive yang sangat terobsesi (Müller et al., 2015) , adiktif / bersifat kecanduan (Maraz et al., 2015), serta perubahan suasana hati dan depresi (Mueller et al., 2011). Perilaku kompulsif dapat bersifat adiksi / membuat pelakunya merasa kecanduan. Duroy et al (2014) menyatakan pada kasus pembelian 
online, para pelaku compulsive buying dapat menghabiskan banyak waktu untuk berbelanja secara online, baik pagi, siang, maupun malam karena sifat toko online yang tidak terbatas waktu.

Dalam penelitian ini dikembangkan hipotesis sesuai dengan determinan yang diteliti. Berikut adalah hipotesis yang dikembangkan untuk diteliti dalam penelitian ini:

Promosi penjualan yang diberikan oleh produsen akan membuat konsumen tertarik untuk membeli secara tidak terencana. Pembelian yang tidak terencana itu dapat meningkatkan peluang terjadinya compulsive buying. Dittmar (2005) dan Claes et al. (2016) menyatakan hipotesis bahwa endorsement yang semakin kuat akan mendorong terjadinya compulsive buying yang semakin kuat pula. Oleh karena itu, hipotesis yang diajukan adalah:

H1: Promosi penjualan berpengaruh positif terhadap compulsive buying.

Feinberg (1986) menyatakan bahwa mahasiswa yang memiliki akses kartu kredit akan lebih mudah mengambil keputusan cepat untuk membeli dan mengeluarkan uang lebih banyak. Pembayaran non tunai akan memberikan kemudahan bagi konsumen dalam berbelanja. Hal ini akan meningkatkan kemungkinan berkurangnya kontrol diri dalam berbelanja, sehingga akan meningkatkan terjadinya compulsive buying. Palan et al. (2011) menunjukkan bahwa para konsumen yang berperilaku kompulsif pada umumnya memiliki kartu kredit sebagai media pembayarannya. Oleh karena itu, hipotesis yang diajukan adalah:

H2: Pembayaran non tunai berpengaruh positif terhadap compulsive buying.

Keberadaan orang di sekitar akan mempengaruhi seseorang dalam pengambilan keputusan pembelian. Keputusan pembelian pun dapat menjadi compulsive buying ketika konsumen tidak memiliki kontrol diri yang baik. Valence et al (1988) menyatakan bahwa kondisi keluarga dapat membentuk karakter seseorang dalam melakukan konsumsi. Compulsive buying sendiri merupakan salah satu bentuk dari perilaku konsumsi yang dimiliki oleh seseorang. Oleh karena itu, dihipotesiskan bahwa lingkungan sosial berpengaruh positif terhadap compulsive buying. Oleh karena itu, hipotesis yang diajukan adalah:

H3: Lingkungan sosial berpengaruh positif terhadap compulsive buying.

Pengelolaan keuangan seseorang merupakan hal yang penting dilakukan untuk mencegah terjadinya compulsive buying. Robert \& Jones (2001) menyatakan bahwa seseorang yang sedang mengalami kecemasan dan stres relatif tidak memiliki kontrol diri yang baik, salah satunya dalam mengontrol kondisi keuangannya. Kecemasan dan stres mendorong seseorang untuk menghamburkan uang dengan melakukan pembelian secara berulang. Diibaratkan bila konsumen yang memiliki uang banyak akan cenderung lebih boros dan sering berbelanja. Sebaliknya, konsumen dengan kondisi ekonomi terbatas akan berbelanja dengan lebih bijak. Namun perlu adanya penelitian apakah benar bila kondisi keuangan seseorang dapat mempengaruhi pola konsumsi yang dilakukannya. Oleh karena itu, hipotesis yang diajukan adalah:

H4: Kondisi keuangan berpengaruh positif terhadap compulsive buying. 


\section{Metode Penelitian}

Penelitian ini dilakukan di Kota Surabaya. Pemilihan kota Surabaya dikarenakan Kota Surabaya adalah kota metropolitan dengan bauran penduduk yang heterogen. Mahasiswa yang umumnya berkuliah di Kota Surabaya berasal dari berbagai daerah dan latar belakang demografi yang sangat bervariasi.

Metode yang digunakan dalam penelitian ini adalah deskriptif dengan desain multiple cross sectional. Pengambilan sampel dilakukan dengan metode convenience sampling, kemudian data dianalisis dengan Structural Equation Modeling (SEM). Dalam menggunakan SEM, digunakan bantuan software AMOS. Sejumlah 575 responden mahasiswa berhasil dikumpulkan dengan menggunakan survey secara online. Untuk menguji keempat hipotesis yang dikembangkan, digunakan lima variabel laten dan dua puluh lima variabel indikator seperti yang terlihat pada Tabel 1. Sedangkan, untuk model penelitian ini digambarkan seperti pada Gambar 1.

Tabel 1. Definisi Operasional Variabel

\begin{tabular}{|c|c|c|}
\hline Variabel Laten & Definisi & Variabel Indikator \\
\hline \multirow{5}{*}{ Promosi penjualan $\left(\mathrm{X}_{1}\right)$} & \multirow{5}{*}{$\begin{array}{l}\text { Media, bentuk dan jumlah penawaran yang diberikan oleh penjual } \\
\text { kepada konsumen untuk menarik minat belanja konsumen } \\
\text { (Rahmat, 2011) }\end{array}$} & $\mathrm{X}_{1.1}$ Iklan \\
\hline & & $\mathrm{X}_{1.2}$ Diskon \\
\hline & & $\mathrm{X}_{1.3}$ Paket promosi \\
\hline & & $\mathrm{X}_{1.4}$ Voucher \\
\hline & & $\mathrm{X}_{1.5}$ Hadiah \\
\hline \multirow{6}{*}{$\begin{array}{l}\text { Pembayaran non tunai } \\
\left(\mathrm{X}_{2}\right)\end{array}$} & \multirow{6}{*}{$\begin{array}{l}\text { Cara pembayaran yang dilakukan konsumen dengan } \\
\text { menggunakan media pembayaran selain uang tunai (Istanto \& } \\
\text { Fauzie, 2014) }\end{array}$} & $\mathrm{X}_{2.1}$ Penggunaan kartu kredit \\
\hline & & $\mathrm{X}_{2.2}$ Keuntungan kartu kredit \\
\hline & & $\mathrm{X}_{2.3}$ Penggunaan kartu debit \\
\hline & & $\mathrm{X}_{2.4}$ Keuntungan kartu debit \\
\hline & & $\mathrm{X}_{2.5}$ e-money card \\
\hline & & $\mathrm{X}_{2.6}$ e-money digital \\
\hline \multirow{5}{*}{ Lingkungan sosial (X3) } & \multirow{5}{*}{$\begin{array}{l}\text { Sesuatu yang berada di sekitar konsumen yang memberikan } \\
\text { pengaruh dalam pengambilan keputusan pembelian (Valence et } \\
\text { al, 1988) }\end{array}$} & X3.1 Keluarga \\
\hline & & X3.2 Kelompok \\
\hline & & X3.3 Orang asing \\
\hline & & X3.4 Salesperson \\
\hline & & X3.5 Situasi \\
\hline \multirow{5}{*}{ Kondisi keuangan (X4) } & \multirow{5}{*}{$\begin{array}{l}\text { Bagaimana kondisi keuangan yang dimiliki seseorang ketika } \\
\text { hendak melakukan pembelian (Robert \& Jones, 2001) }\end{array}$} & X4.1 Jumlah pendapatan \\
\hline & & X4.2 Welfare \\
\hline & & X4.3 Money saved \\
\hline & & X4.4 Money attitudes \\
\hline & & X4.5 Money spended \\
\hline \multirow{5}{*}{ Compulsive buying (Y1) } & \multirow{5}{*}{$\begin{array}{l}\text { Keinginan untuk membeli sehingga membuat seseorang } \\
\text { kehilangan kontrol diri (Dittmar, 2005) }\end{array}$} & Y1.1 Overbuying \\
\hline & & Y1.2 Penyesalan \\
\hline & & Y1.3 Unused \\
\hline & & Y1.4 Adiksi \\
\hline & & Y1.5 Anxiety \\
\hline
\end{tabular}




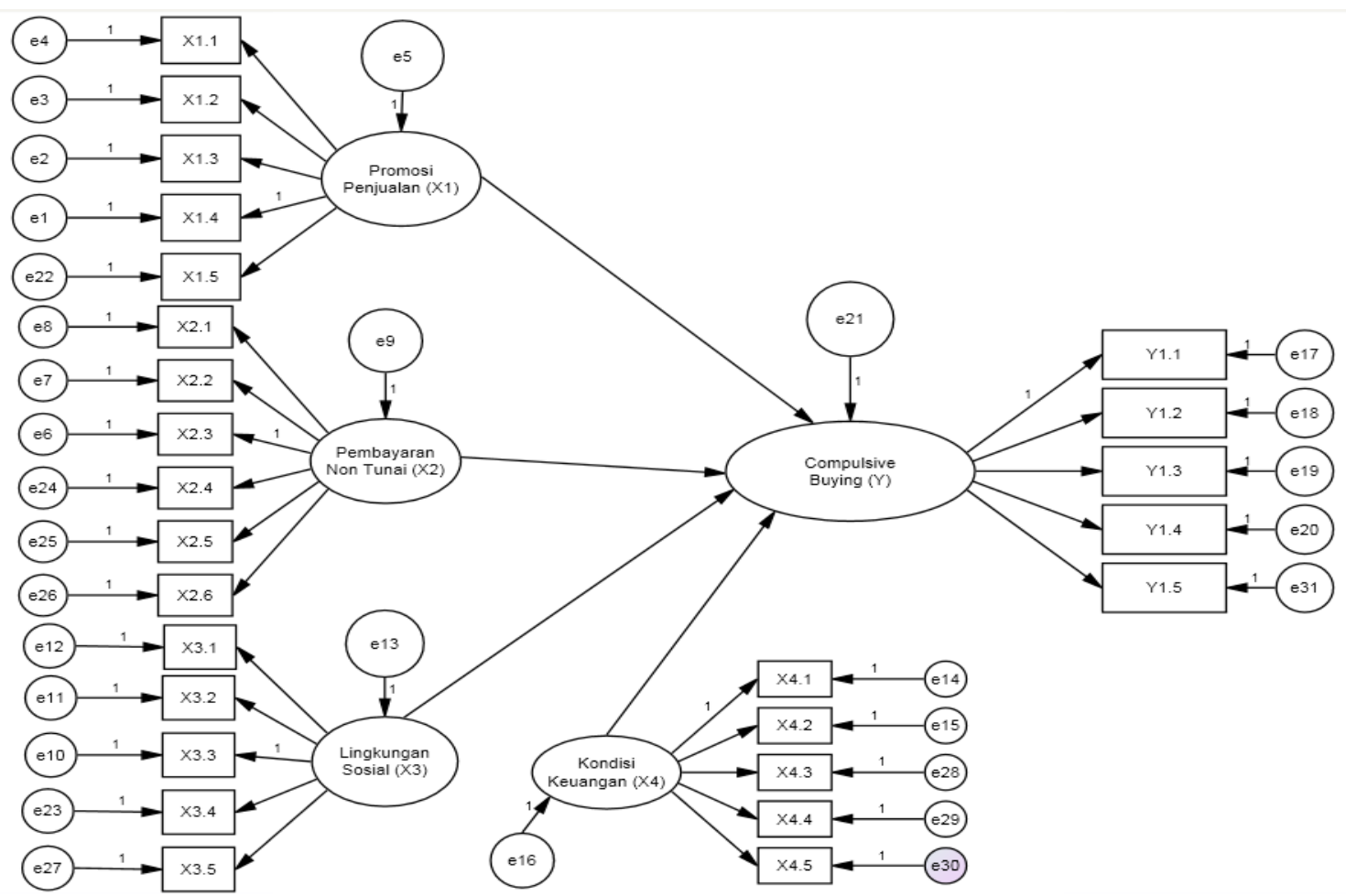

\section{Hasil Penelitian dan Pembahasan}

Peneliti melakukan analisis deskriptif terlebih dahulu untuk mengetahui profil responden untuk data keseluruhan dari kuesioner demografi dan usage (Wibawa \& Bramanti, 2018). Analisis demografi responden meliputi data demografi responden seperti jenis kelamin, usia, asal universitas, pendapatan/uang saku, dan pengeluaran (Tabel 2).

Tabel 2. Demografi Responden

\begin{tabular}{|c|c|}
\hline Profil Responden & Persentase $(\%)$ \\
\hline \multicolumn{2}{|l|}{ Jenis Kelamin } \\
\hline Laki-laki & 33,2 \\
\hline Perempuan & 66,8 \\
\hline Total & 100,0 \\
\hline \multicolumn{2}{|l|}{ Usia } \\
\hline$\leq 18$ tahun & 14,9 \\
\hline 19 tahun & 12,3 \\
\hline 20 tahun & 22,8 \\
\hline 21 tahun & 37,9 \\
\hline 22 tahun & 9,5 \\
\hline$\geq 23$ tahun & 2,6 \\
\hline Total & 100,0 \\
\hline \multicolumn{2}{|l|}{ Klasifikasi Perguruan Tinggi } \\
\hline PTN & 49,5 \\
\hline PTS & 50,5 \\
\hline Total & 100,0 \\
\hline \multicolumn{2}{|l|}{ Pendapatan /uang saku per bulan } \\
\hline$\leq \mathrm{Rp} 1.000 .000$ & 38,9 \\
\hline $\operatorname{Rp} 1.000 .001-1.500 .000$ & 32,3 \\
\hline $\operatorname{Rp} 1.500 .001-2.000 .000$ & 15,2 \\
\hline$\geq \operatorname{Rp} 2.000 .001$ & 13,6 \\
\hline Total & 100,0 \\
\hline \multicolumn{2}{|l|}{ Pengeluaran per bulan } \\
\hline$\leq \mathrm{Rp} 1.000 .000$ & 49,6 \\
\hline
\end{tabular}




\begin{tabular}{lr}
\hline \multicolumn{1}{c}{ Profil Responden } & Persentase $(\%)$ \\
Rp $1.000 .001-1.500 .000$ & 32,0 \\
Rp $1.500 .001-2.000 .000$ & 11,1 \\
$\geq$ Rp 2.000 .001 & 7,3 \\
Total & 100,0 \\
Frekuensi ke pusat perbelanjaan per bulan & 17,3 \\
$\leq 1$ kali & 55,3 \\
$2-3$ kali & 20,0 \\
$4-5$ kali & 3,6 \\
$6-7$ kali & 3,8 \\
$\geq 8$ kali & 100,0 \\
Total & 7,1 \\
$\leq 1$ jam & 49,9 \\
2-3 jam & 38,6 \\
$4-5$ jam & 2,8 \\
6-7 jam & 1,6 \\
Rata-ram lama waktu berbelanja di pusat perbelanjaan & 100,0 \\
\hline
\end{tabular}

Sedangkan untuk data usage meliputi deskripsi perilaku yang dilakukan oleh responden etika berbelanja dalam kondisi stress (Tabel 3).

Tabel 3. Analisis Penggunaan Responden

\begin{tabular}{|c|c|}
\hline Profil & Persentase $(\%)$ \\
\hline \multicolumn{2}{|l|}{ Pernah berbelanja dalam kondisi stress } \\
\hline Ya & 69,2 \\
\hline Tidak & 30,8 \\
\hline Total & 100,0 \\
\hline \multicolumn{2}{|c|}{ Barang / jasa yang dibeli ketika berbelanja dalam keadaan stress } \\
\hline Aksesoris & 6,5 \\
\hline Buku & 3,9 \\
\hline Jasa & 21,3 \\
\hline Makanan / minuman & 44,7 \\
\hline Pakaian & 19,0 \\
\hline Produk kecantikan & 4,3 \\
\hline Rokok / vapor & 0,3 \\
\hline Total & 100,0 \\
\hline \multicolumn{2}{|c|}{ Penggunaan barang yang dibeli ketika berbelanja dalam keadaan stress } \\
\hline Ya & 96,7 \\
\hline Tidak & 3,3 \\
\hline Total & 100,0 \\
\hline \multicolumn{2}{|c|}{ Kondisi barang yang dibeli ketika berbelanja dalam keadaan stress } \\
\hline Masih baik dan masih digunakan & 35,7 \\
\hline Masih baik namun tidak digunakan & 5,0 \\
\hline Mulai rusak & 0,5 \\
\hline Sudah habis & 58,8 \\
\hline Total & 100,0 \\
\hline \multicolumn{2}{|c|}{ Rata-rata pengeluaran ketika berbelanja dalam keadaan stress } \\
\hline$\leq \operatorname{Rp} 100.000$ & 44,3 \\
\hline Rp $100.001-200.000$ & 29,8 \\
\hline $\operatorname{Rp} 200.001-300.000$ & 13,9 \\
\hline$\geq \operatorname{Rp} 300.001$ & 12,0 \\
\hline Total & 100,0 \\
\hline \multicolumn{2}{|l|}{ Jenis pembayaran yang disukai } \\
\hline Kartu kredit & 12,7 \\
\hline Kartu debit & 68,0 \\
\hline e-money berbentuk kartu & 8,2 \\
\hline e-money berbentuk digital & 11,1 \\
\hline Total & 100,0 \\
\hline
\end{tabular}


Analisis deskriptif dilakukan juga pada variabel komposit penelitian. Variabel komposit diperoleh dari penggabungan variabel-variabel indikator sehingga didapatkan sebuah variabel yang mewakili tiap indikator. Berikut merupakan hasil analisis deskriptif pada variabel komposit (Tabel 4.).

Tabel 4. Variabel Komposit

\begin{tabular}{ccccccccc}
\hline $\begin{array}{c}\text { Variabel } \\
\text { Komposit }\end{array}$ & $\begin{array}{c}\text { Jumlah } \\
\text { Item }\end{array}$ & Sum & Mean & Std. Error & Std. Dev & Variance & Skewness & Kurtosis \\
\hline PP (X1) & 4 & 2118,00 & 3,69 & 0,33 & 0,79 & 0,62 & $-0,74$ & 0,73 \\
PNT (X2) & 3 & 1755,40 & 3,05 & 0,34 & 0,82 & 0,67 & $-0,20$ & 0,06 \\
LS (X3) & 3 & 1782,50 & 3,10 & 0,35 & 0,83 & 0,69 & $-0,09$ & 0,01 \\
KK (X4) & 3 & 1987,33 & 3,46 & 0,35 & 0,85 & 0,72 & $-0,37$ & $-0,13$ \\
CB (Y1) & 3 & 1716,33 & 2,98 & 0,45 & 1,08 & 1,16 & $-0,04$ & $-0,70$ \\
\hline
\end{tabular}

Setelah tahapan respesifikasi, terdapat perubahan nilai GOF menjadi lebih fit. Sebelum dilakukan respesifikasi, terdapat beberapa nilai GOF yang belum mencapai cut-off-value. Namun setelah dilakukan tahapan respesifikasi, nilai GOF telah mencapai standar yang ditetapkan. Bila nilai GOF telah memenuhi cutoff-value, maka model yang dibentuk dianggap diterima dan dapat dilakukan interpretasi pada koefisien jalur (Sarwono, 2009). Dengan demikian, model yang digunakan pada penelitian ini dianggap sudah baik (Tabel 5).

Tabel 5. Goodness of Fit

\begin{tabular}{|c|c|c|c|c|c|c|}
\hline \multirow[t]{2}{*}{ No } & \multirow{2}{*}{$\begin{array}{c}\text { Goodness of Fit } \\
\text { Measure }\end{array}$} & \multirow[t]{2}{*}{ Cut-off value } & \multicolumn{2}{|c|}{ Sebelum Respesifikasi } & \multicolumn{2}{|c|}{ Setelah Respesifikasi } \\
\hline & & & Nilai & Keterangan & Nilai & Keterangan \\
\hline \multicolumn{7}{|c|}{ Absolute Fit Indices } \\
\hline 1 & Chi squares & $<106,395$ & 577,17 & Tidak Fit & 453,97 & Tidak Fit \\
\hline 2 & GFI & $\geq 0,9$ & 0,87 & Marginal & 0,91 & Fit \\
\hline 3 & RMR & $\leq 0,08$ & 0,19 & Tidak Fit & 0,17 & Tidak Fit \\
\hline 4 & RMSEA & $<0,08$ & 0,09 & Marginal & 0,08 & Fit \\
\hline \multicolumn{7}{|c|}{ Incremental Fit Indices } \\
\hline 5 & AGFI & $\geq 0,9$ & 0,83 & Tidak Fit & 0,87 & Marginal \\
\hline 6 & NFI & $\geq 0,9$ & 0,85 & Marginal & 0,89 & Marginal \\
\hline 7 & CFI & $\geq 0,9$ & 0,88 & Marginal & 0,91 & Fit \\
\hline 8 & IFI & $\geq 0,9$ & 0,88 & Marginal & 0,91 & Fit \\
\hline \multicolumn{7}{|c|}{ Parsimony Fit Indices } \\
\hline 9 & PNFI & $0,60-0,90$ & 0,71 & Fit & 0,72 & Fit \\
\hline 10 & PGFI & $0,50-1,00$ & 0,64 & Fit & 0,65 & Fit \\
\hline
\end{tabular}

Berikut adalah hasil uji hipotesis yang dilakukan dengan menggunakan analisis Structural Equation Modeling (SEM). Uji hipotesis dilakukan dengan melihat nilai $p$-value dari hubungan antar variabel. Nilai signifikansi $\mathrm{p}$-value yang digunakan dalam penelitian ini adalah $<0,05$. Apabila nilai $\mathrm{p}$-value lebih besar dari 0,05 maka hipotesis ditolak, sedangkan nilai p-value lebih kecil dari 0,05 maka hipotesis akan diterima. Tanda panah $(\rightarrow)$ menunjukkan arah pengaruh antara variabel satu dengan variabel lainnya. Nilai standardize coefficient $(\beta)$ positif menunjukkan adanya hubungan positif antar variabel.

Tabel 6. Hasil Uji Hipotesis

\begin{tabular}{|c|c|c|c|c|c|}
\hline Hipotesis & & Pengaruh & Standardize & $P$ & Keterangan \\
\hline H1 & Promosi penjualan & Compulsive buying & 0,24 & $<0,001 *$ & Signifikan \\
\hline $\mathrm{H} 2$ & $\begin{array}{l}\text { Pembayaran Non } \\
\text { Tunai }\end{array}$ & Compulsive buying & 0,28 & $<0,001^{*}$ & Signifikan \\
\hline $\mathrm{H} 3$ & Lingkungan Sosial & Compulsive buying & 0,13 & 0,063 & Tidak Signifikan \\
\hline $\mathrm{H} 4$ & Kondisi Keuangan & Compulsive buying & 0,12 & $0,009 *$ & Signifikan \\
\hline
\end{tabular}




\section{Uji Hipotesis 1 (Promosi penjualan berpengaruh positif terhadap compulsive buying)}

Mahasiswa di Surabaya yang berperilaku kompulsif memiliki pengalaman yang positif terhadap promosi penjualan. Mereka melakukan pembelian secara kompulsif karena terpengaruh oleh promosi penjualan. Mereka sering kali membeli dengan alasan harga yang lebih murah, adanya hadiah, maupun keuntungan lain yang diperolehnya. Di Surabaya, perusahaan ritel membuat strategi untuk memenangkan persaingan dengan cara memberikan promosi harga yang murah didukung dengan kualitas dan fasilitas toko ritel (Tan, 2011). Promosi penjualan yang dilakukan berupa potongan harga, pemberian harga yang lebih murah ketika membeli dalam jumlah tertentu, pemberian voucher belanja, hadiah, dan lainnya. Berdasarkan hasil analisis SEM, konstruk promosi penjualan memiliki nilai standardize coefficient $(\beta)$ sebesar 0,24 dan p-value kurang dari 0,001 . Arah pengaruh yang ditunjukkan adalah positif dan nilai $p$-value kurang dari 0,05 , artinya hipotesis 1 dinyatakan diterima.

H1: Promosi penjualan berpengaruh positif terhadap compulsive buying) - diterima.

\section{Uji Hipotesis 2 (Pembayaran non tunai berpengaruh positif terhadap compulsive buying)}

Penggunaan pembayaran non tunai akan membuat konsumen memiliki kesempatan untuk memenuhi kepuasan berbelanjanya. Dengan sistem pembayaran non tunai, maka konsumen relatif tidak lagi begitu peduli dengan harga barang / jasa yang hendak dibelinya (Lo \& Harvey, 2011). Kebebasan menggunakan pembayaran non tunai dengan tidak bijak akan membuat mahasiswa terus membeli dan membeli tanpa mempedulikan masalah keuangan yang mungkin timbul di kemudian harinya. Berdasarkan hasil analisis SEM, konstruk pembayaran non tunai memiliki nilai standardize coefficient $(\beta)$ sebesar 0,28 dan p-value kurang dari 0,001. Arah pengaruh yang ditunjukkan adalah positif dan nilai $p$-value kurang dari 0,05 , artinya hipotesis 2 dinyatakan diterima.

H2: Pembayaran non tunai berpengaruh positif terhadap compulsive buying - diterima.

\section{Uji Hipotesis 3 (Lingkungan sosial berpengaruh positif terhadap compulsive buying)}

Berdasarkan hasil analisis SEM, konstruk promosi penjualan memiliki nilai standardize coefficient ( $\beta$ ) sebesar 0,13 dan $p$-value sebesar 0,063. Arah pengaruh yang ditunjukkan adalah positif namun nilai $p$-value lebih dari 0,05, artinya hipotesis 3 dinyatakan ditolak. Hal ini menandakan tidak adanya pengaruh-pengaruh dari lingkungan sekitar membuat seseorang memiliki dorongan untuk melakukan pembelian secara kompulsif.

H3: Lingkungan sosial berpengaruh positif terhadap compulsive buying - ditolak

\section{Uji Hipotesis 4 (Kondisi keuangan berpengaruh positif terhadap compulsive buying)}

Terjadinya compulsive buying juga didorong oleh kondisi keuangan yang dimiliki oleh konsumen. Hal tersebut didasari pada prinsip ekonomi, bahwa semakin tinggi taraf hidupnya maka akan semakin banyak pula kebutuhan hidupnya (Paturochman, 2005). Peningkatan kondisi keuangan akan berimbas pada meningkatnya jumlah pembelian yang dilakukan untuk memenuhi kebutuhan hidupnya. Kondisi keuangan mahasiswa menjadi kunci dalam pengambilan keputusan pembelian. Mahasiswa sering kali mempertimbangkan kondisi keuangannya dalam membeli barang/jasa. Pada saat ini, banyak anak muda yang hidup dalam budaya dimana mengeluarkan uang merupakan sebuah kehormatan dan justru menghindari kebiasaan menabung (Robert \& Jones, 2001). Berdasarkan hasil analisis SEM, konstruk promosi penjualan memiliki nilai standardize 
coefficient $(\beta)$ sebesar 0,12 dan $p$-value sebesar 0,009 . Arah pengaruh yang ditunjukkan adalah positif dan nilai $p$-value kurang 0,05 , artinya hipotesis 4 dinyatakan diterima.

H4. Kondisi keuangan berpengaruh positif terhadap compulsive buying - diterima

\section{Implikasi Manajerial}

Implikasi manajerial dilihat dari dua sudut pandang yang berbeda yaitu, dari sudut pandang konsumen dan sudut pandang pemasar. Implikasi pertama yang dibahas adalah implikasi manajerial untuk konsumen. Berdasarkan hasil analisis SEM, konsumen tidak lagi peduli dengan kondisi keuangan mereka dalam berbelanja. Mereka tetap berusaha melakukan pembelian sekalipun kondisi keuangan mereka tidak memiliki toleransi kelonggaran yang cukup. Sedangkan dari sudut pandang pemasar, hendaknya pemasar menciptakan keseimbangan dalam mencari laba, memuaskan kebutuhan dan keinginan konsumen serta menjaga kesejahteraan masyarakat dalam jangka panjang. Perilaku kompulsif ini merupakan sebuah perilaku sosial dan budaya yang negatif, sehingga perlu adanya sebuah kebijakan yang mempertimbangkan adanya dampak negatif dari perilaku kompulsif (Shoham \& Brencic, 2003).

Terdapat implikasi manajerial lain yang perlu dilakukan oleh pemasar. Pemasar perlu bekerja sama dengan pemerintah untuk menciptakan sebuah kampanye tentang berbelanja yang baik. Dengan berbelanja yang baik, maka konsumen dapat menghindari konsekuensi dari belanja secara berlebihan. Adanya kampanye ini diharapkan meningkatkan kesadaran masyarakat mengenai perilaku berbelanja yang baik. Di sisi lain, pemasar tidak akan dirugikan karena pemasar akan memperoleh citra yang positif di mata konsumen. Hal ini membuat pemasar memperoleh daya tarik tersendiri bagi konsumen yang menginginkan berbelanja dengan baik.

\section{Kesimpulan}

Terdapat pengaruh yang positif dan signifikan dari variabel promosi penjualan, pembayaran non tunai, dan kondisi keuangan terhadap compulsive buying pada mahasiswa di Surabaya. Sedangkan lingkungan sosial tidak berpengaruh pada terjadinya compulsive buying. Hal ini menunjukkan bahwa semakin banyak promosi penjualan yang diberikan oleh penjual akan mendorong terjadinya compulsive buying yang semakin tinggi pula. Penggunaan media pembayaran non tunai juga mempermudah proses transaksi belanja sehingga mendorong terjadinya compulsive buying. Kondisi keuangan yang baik akan meningkatkan kemungkinan terjadinya compulsive buying pada mahasiswa di Surabaya.

Penelitian ini memiliki keterbatasan hasil penelitian, diantaranya hasil penelitian dianalisis berdasarkan sudut pandang mahasiswa yang memiliki kecenderungan perilaku compulsive buying, namun belum divalidasi secara psikologi maupun medis apakah mahasiswa tersebut benar-benar memiliki perilaku kompulsif atau tidak. Oleh karena itu, pada penelitian selanjutnya diperlukan sebuah validasi terhadap responden, untuk membuktikan responden tersebut berperilaku kompulsif dari aspek psikologi maupun medis. Penelitian selanjutnya direkomendasikan untuk menganalisis perbandingan responden antara mahasiswa yang berperilaku kompulsif dan yang tidak berperilaku kompulsif, sehingga dapat diketahui secara signifikan perbedaan perilaku pembelian antara kedua kelompok tersebut. 


\section{Daftar Pustaka}

Achtziger, A., Hubert, M., Kenning, P., \& Raab, G. (2015). Debt out of control: The links between self-control, compulsive buying, and real debts. Journal of Economic Psychology, 49, 141-149.

Christenson, G., Faber, R., de Zwaan, M., \& Raymond, N. (1994). Compulsive Buying: Descriptive Characteristics and Psychiatric Comorbidity. Journal of Clinical Psychiatry, 55(1), 5-11.

Claes, L., Müller, A., \& Luyckx, K. (2016). Compulsive buying and hoarding as identity substitutes: The role of materialistic value endorsement and depression. Comprehensive Psychiatry, 68, 65-71.

Dittmar, H. (2005). Compulsive Buying - A Growing Concern? An Examination of Gender, Age and Endorsement of Materialistic Attitudes as Predictors. British Journal of Psychology, 96(4), 467-491.

Duroy, D., Gorse, P., \& Lejoyeux, M. (2014). Characteristics of Online Compulsive Buying in Parisian Students. Addictive Behaviors, 39(12), 1827-1830.

Faber, R., Christenson, G., de Zwaan, M., \& Mitchell, J. (2014). Two Forms of Compulsive Consumption: Comorbidity of Compulsive Buying and Binge Eating. Journal of Consumer Research, 22(3), 296 304.

Felicia, F., Elvinawaty, R., \& Hartini, S. (2014). Kecenderungan Pembelian Kompulsif: Peran Perfeksionisme dan Gaya Hidup Hedonistik. Psikologia: Jurnal Pemikiran dan Penelitian Psikologi, 9(3).

Hassay, D., \& Smith, M. (1996). Compulsive Buying: An Examination of the Consumption Motive. Psychology and Marketing, 13(8), 741-752.

Kellett, S., \& Bolton, J. (2009). Compulsive buying: A cognitive-behavioural model. Clinical Psychology \& Psychotherapy: An International Journal of Theory \& Practice, 16(2), 83-99.

King, A. (1981). Beyond Propensities: Toward a Theory of Addictive Consumption, The Changing Marketing Environment: New Theories. Chicago: American Marketing Association.

Lawrence, L., Ciorciari, J., \& Kyrios, M. (2014). Relationships that compulsive buying has with addiction, obsessive-compulsiveness, hoarding, and depression. Comprehensive psychiatry, 55(5), 1137-1145.

Lo, H., \& Harvey, N. (2011). Shopping Without Pain: Compulsive Buying and the Effects of Credit Card Availability in Europe and the Far East. Journal of Economic Psychology, 32(1), 79-92.

Maraz, A., van den Brink, W., \& Demetrovics, Z. (2015). Prevalence and construct validity of compulsive buying disorder in shopping mall visitors. Psychiatry research, 228(3), 918-924.

Mueller, A., Mitchell, J., Peterson, L., Faber, R., Steffen, K., Crosby, R., \& Claes, L. (2011). Depression, materialism, and excessive Internet use in relation to compulsive buying. Comprehensive Psychiatry, 52(4), 420-424.

Müller, A., Mitchell, J., \& de Zwaan, M. (2015). Compulsive buying. The American Journal on Addictions, 24(2), 132-137.

Murray, H. (1953). Exploration de lapersonnalit. Paris.

Naomi, P., \& Mayasari, I. (2008). Faktor-Faktor yang Mempengaruhi Siswa SMA dalam Perilaku Pembelian Kompulsif: Perspektif Psikologi. Jurnal Abmas, 1-8.

Palan, K., Morrow, P., Trapp, A., \& Blackburn, V. (2011). Compulsive buying behavior in college students: the mediating role of credit card misuse. Journal of Marketing Theory and Practice, 19(1), 81-96.

Parzalis, P., Katsigiannopoulos, K., \& Papa, G. (2008). Compulsive Buying - A review. Annals of Genral Psychiatry, 7(1).

Paturochman, M. (2005). Hubungan Antara Tingkat Pendapatan Keluarga Peternak dengan Tingkat Konsumsi (Kasus di Koperasi Peternakan Bandung Selatan Pangalengan). Sosiohumaniora, 7(3), 264-272.

Raab, G., Eldger, C., Neuner, M., \& Weber, B. (2011). A Neurological Study of Compulsive Buying Behavior. Journal of Consumer Policy, 34(4), 401-413.

Sarwono, J. (2009). Statistik itu mudah: Panduan Lengkap untuk Belajar Komputasi Statistik Menggunakan SPSS. Yogyakarta: CV. Andi Offset.

Shoham, H., \& Brencic, M. (2003). Compulsive Buying Behavior. Journal of Consumer Marketing, 20(2), 127-138.

Tan, E. (2011). Pengaruh Faktor Harga, Promosi dan Pelayanan Terhadap Keputusan Konsumen untuk Belanja di Alfamart Surabaya. Jurnal Kewirausahaan, 5 (2): 25-30., 5(2), 25-30.

Valence, G., d'Astous, A., \& Fortier, L. (1988). Compulsive Buying: Concept and Measurement. Journal of Consumer Policy, 11(4), 419-433. 
Weinstein, A., Maraz, A., Griffiths, M., Lejoyeux, M., \& Demetrovics, Z. (2016). Compulsive buyingfeatures and characteristics of addiction. Neuropathology of drug addictions and substance misuse, 993-1007.

Wibawa, B., \& Bramanti, G. (2018). Analisis Model Struktural Faktor-Faktor Pembentuk Fashion-Oriented Impulse Buying Produk Ritel Fashion berdasarkan Sudut Pandang Konsumen Usia Remaja. DeReMa Jurnal Manajemen, 13(1), 55-82. 